\title{
Influenza surveillance in poultry market and its inter-species transmission in Taiwan
}

\author{
H.-L. Yen ${ }^{\mathrm{a}}$, M.-C. Cheng ${ }^{\mathrm{b}}$, J.L. Liu ${ }^{\mathrm{a}}$, C.-L. Kao ${ }^{\mathrm{c}}$, S.R. Shih ${ }^{\mathrm{d}}$, \\ N.J. Cox ${ }^{\mathrm{e}}$, R.G. Webster ${ }^{\mathrm{f}}$, C.-C. King ${ }^{\mathrm{a}, *}$ \\ ${ }^{a}$ Institute of Epidemiology, College of Public Health, National Taiwan University (NTU), No. 1, \\ Jen-Ai Road Section 1, Taipei, Taiwan \\ ${ }^{\mathrm{b}}$ National Institute for Animal Health, Council of Agriculture, Taipei, Taiwan \\ ${ }^{\mathrm{c}}$ School of Medical Technology, National Taiwan University, Taipei, Taiwan \\ ${ }^{\mathrm{d}}$ School of Medical Technology, Chang-Gung University, Taoyuan, Taiwan \\ e Influenza Branch, Centers for Disease Control and Prevention, Atlanta, GA, USA \\ ${ }_{\mathrm{f}}^{\mathrm{f}}$. Jude Children's Research Hospital, Memphis, TN, USA
}

\begin{abstract}
Background: Since Taiwan has high population density and a similar ecological environment to Mainland China, the epi-center of influenza viruses, it is very important to establish influenza virologic surveillance systems in both animal and human populations. The H5N1 Hong Kong Flu in 1997 and H9N2 in 1999 have showed that avian influenza viruses can cross the receptor of host species boundary and transmit to human. Therefore, the specific aim of this study is to understand the frequency of inter-species transmission in Taiwan. Methods: We have established an avian influenza virologic surveillance system in one of the largest live poultry markets in Taipei City from October 1999 to March 2000. Serum samples were collected from 341 blood donors, including veterinarians, poultry farm workers, and market employees. $\mathrm{HI}$ and microneutralization were used to detect specific antibody against H6, an endemic virus in chicken farms in southern Taiwan, and antibodies against $\mathrm{H} 3, \mathrm{H} 4$, and $\mathrm{H} 9$ viruses. Results: Among about 1300 fecal specimens of chickens and ducks collected, we isolated $12 \mathrm{H} 3$ viruses, $14 \mathrm{H} 4$ viruses, and $2 \mathrm{H} 6$ viruses (i.e. 9 serotypes of HA and NA) from ducks. The isolation rates were $0 \%(0 / 580)$ and $7 \%(28 / 400)$ in chickens and ducks, respectively. Phylogenetic analysis of HA from 7 of our $12 \mathrm{H} 3$ isolates showed the highest (93\%) homology with A/equine/Jilin/89 (H3N8). Both phylogenetic relationship of HA and NP genes from selected representative strains $(7 \mathrm{H} 3,7 \mathrm{H} 4$, and $2 \mathrm{H} 6)$ found they all fell into Eurasian lineage of avian influenza viruses. Their NP genes were away from the G1 lineage that was found in H5N1 strain isolated in Hong Kong in 1997. In addition, the results of HI and microneutralization tests found that they were all seronegative against two avian influenza virus strains [A/Duck/
\end{abstract}

\footnotetext{
${ }^{*}$ Corresponding author. Tel.: +886-2-2341-4347; fax: +886-2-2351-1955.

E-mail address: a1234567@ccms.ntu.edu.tw (C.-C. King).
} 
Czechoslovakia/56 (H4N6) and A/Shearwater/Australia/1/72 (H6N5)]. Conclusion: Continuous efforts by integrating animal, market and human influenza surveillance systems have provided the best early warning signals to detect new influenza virus activities for preventing potential pandemics and providing effective controls. (C) 2001 Elsevier Science B.V. All rights reserved.

Keywords: Market Surveillance; Influenza; Zoonosis; Taiwan

\section{Introduction}

Avian influenza viruses are considered to be the ancient source of equine, swine, and human influenza viruses' molecular evolution, with aquatic birds as the natural reservoirs of $15 \mathrm{HA}$ and 9 NA serotypes [1]. Although these viruses tend to achieve evolutionary balance and do not lead to disease in their natural reservoirs, they periodically infect domestic poultry. Particularly, H5 and H7 subtypes may result in economic loss [2,3]. On the other hand, interspecies transmission of avian influenza viruses to mammalian animals including horses, pigs, whales, dolphins, and minks occurs less frequently. Pigs with receptors of both avian and humans have been proposed to serve as an intermediate host for reassortant viruses, which could subsequently infect human population and probably cause a pandemic outbreak [4-7]. This concept was challenged in 1997 when avian influenza $\mathrm{H} 5 \mathrm{~N} 1$ virus was demonstrated to transmit directly from domestic poultry to humans in Hong Kong and resulted in 6 deaths out of 18 confirmed cases, raising the concern that chickens may also be an intermediate host [8-10]. The epidemiologic significance of chickens was further supported in 1999, when avian influenza virus H9N2 serotype caused five human cases in Southern China, and two other cases in Hong Kong $[11,12]$. In order to prepare for the future pandemic, continuous and collaborative surveillance systems of human, domestic poultry, pigs and wild birds are the most effective prevention strategy.

Extensive studies on animal influenza viruses in domestic poultry in Hong Kong and southern China have been documented by Dr. K.F. Shortridge since the 1970s [13]. Earlier surveillance results found that influenza viruses were predominantly isolated from ducks and less frequently from chickens and other species. However, recent studies have shown a reverse pattern in that influenza virus is endemic in poultry in southern China, especially the H9N2 subtype which predominantly appeared in chickens and quails. Furthermore, genetic analysis of human $\mathrm{H} 5 \mathrm{~N} 1$ and $\mathrm{H} 9 \mathrm{~N} 2$ viruses revealed high homology (98\%) compared to G1 lineage viruses in their six internal genes [14,15]. These findings indicate that pandemic strains might emerge from reassorted internal genes of those circulating strains, which were derived from avian domestic poultry but could be related to infection and replication in humans.

In Taiwan, domestic poultry influenza surveillance in the past found ducks had higher infection rates than other domestic avian species. Serological surveillance in 1980s showed that the seropositive rates were $3.7 \%(56 / 2056)$ in chickens, $19.8 \%(845 / 4274)$ in ducks, $2.3 \%(4 / 177)$ in turkeys, and $9.1 \%(1 / 11)$ in quails [16]. In addition, the isolation rates of avian influenza viruses among cloacal swabs collected from chickens, ducks, and wild waterfowls in $1986-1988$ were $0.53 \%(7 / 1322), 0.85 \%(13 / 1524)$, and $1.6 \%(3 / 188)$, 
respectively, through active virologic surveillance [17]. Moreover, the isolation rate of avian influenza viruses became higher and reached $2.68 \%$ among 1420 fecal specimens, trachea and cloacal swabs collected from chicken breeders in middle Taiwan in 19901991. However, no active surveillance study has been conducted since 1991. The Hong Kong Flu incident in 1997 accelerated the Council of Agriculture and Poultry Health Centers in Taiwan to initiate an ELISA antibody screening test against nucleoprotein of avian influenza A virus in domestic poultry. However, the avian influenza virologic baseline data were lacking. Therefore, we established a poultry market surveillance system in the largest wholesale market, which sells about 60,000-70,000 chickens and 50,000 ducks per day in Taipei City from October 1999 to March 2000. The specific aims of this study were: (1) to understand current circulating avian influenza viruses in domestic poultry in Taiwan, (2) to investigate the possibility of interspecies transmission of these viruses to Taiwanese population, and (3) to provide more information on the gene pool data base of avian influenza viruses in Asia. Our market influenza active surveillance obtained all 28 avian market virus isolates from ducks that belong to nine serotypes of HA and NA combinations. Phylogenetic relationship of HA and NP genes from selected strains found that they all belong to the Eurasian lineage of avian influenza viruses, and their NP genes were away from the G1 lineage. In addition, further seroepidemiologic investigation among 195 poultry workers and 146 veterinarians distributed all over Taiwan did not find any single seropositive individual against two avian influenza virus strains [A/ Duck/Czechoslovakia/56 (H4N6) and A/Shearwater/Australia/1/72 (H6N5)]. Our preliminary virologic surveillance and seroepidemiologic data indicate that the possibility of direct transmission of new avian influenza virus virulent strains to humans in Taiwan during 1999-2000 season was extremely low.

\section{Materials and methods}

\subsection{Poultry market}

The wholesale market A located in Taipei city is the main source of chickens and ducks at retail markets in Taipei City and Taipei County. In general, about 60,000-70,000 chickens and 50,000 ducks on average, coming from different counties in Taiwan, were transported to market A every day, except special holidays, according to the Chinese traditional lunar calendar. During the period of sampling, chickens sold in market A involved Simulated Native Chicken, Native Chickens, Silky Chickens, and old layers. The wholesale ducks included Peking Duck, Kaiya Duck and Muscovy Duck. Live chickens are usually sold at different retail markets but all ducks were slaughtered at market A. Those chickens that were not sold on the first arrival day would stay at the market for 2-3 days, while all ducks were slaughtered every day.

\subsection{Field specimens}

About 100 fresh fecal samples were collected biweekly from cages or trucks that were transported to the poultry market A from October 1999 to March 2000. Every three fecal 
specimens obtained from the same flock of chickens or ducks were put together into one collection media tube. All of these tubes contained medium 199 (Gibco), $4000 \mathrm{U} / \mathrm{ml}$ Penicillin G, $4 \mathrm{mg} / \mathrm{ml}$ Streptomycin sulfate, $2000 \mathrm{U} / \mathrm{ml}$ Polymyxin B, $500 \mu \mathrm{g} / \mathrm{ml}$ Gentamicin, $500 \mathrm{U} / \mathrm{ml}$ Nystatin, $20 \mu \mathrm{g} / \mathrm{ml}$ Ofloxacin $\mathrm{HCl}$, and $200 \mathrm{ug} / \mathrm{ml}$ Sulfamethoxazole [obtained from Dr. Robert G. Webster]. In total, about 600 chicken feces and 700 duck fecal specimens were collected. These samples were passaged in allantoic cavity of 10-day-old specific-pathogen-free (SPF) chicken embryonic eggs. Those allantoic fluid samples with a positive result of hemagglutination test were further subtyped by hemagglutination inhibition and neuraminidase inhibition tests with monospecific antisera obtained from Dr. K. Kida and Dr. Robert G. Webster followed standard procedures as described [18].

\subsection{RNA extraction and polymerase chain reaction (PCR)}

Viral RNA was extracted from allantoic fluid by using RNeasy Mini Kit (Qiagen, Chatsworth, CA). Complement DNA was synthesized with Uni12 and reverse transcriptase (AMV), and cDNA was amplified by PCR using gene specific primers obtained from $\mathrm{Dr}$. Lee, and $\mathrm{Xu}$ et al. [19]. PCR products were analyzed by $1 \%$ agarose gel electrophoresis and further purified by QIAquick PCR Purification Kit (Qiagen).

\subsection{Gene sequencing and phylogenetic analysis}

Representative viruses of the same HA subtype and derived from the same geographic location were randomly chosen for further genetic analyses. All the selected strains for HA phylogenetic analysis were also used for obtaining their NP gene sequences. Purified PCR products were sequenced with synthetic oligonucleotides by using Rhodamine DyeTerminator Cycle Sequencing Kit with AmpliTaq DNA polymerase FS and an ABI model 377 DNA Sequencer (Perkin-Elmer/Applied Biosystems). Sequence data were edited by the computer packages of DNAStar and GeneDoc. The WISCONSIN Sequence Analysis Package, Version 10.0 (GCG) was used for further analyses and comparison. Phylogenetic analysis was performed with Maximum Parsimony method of PAUP (Phylogenetic Analysis Using Parsimony, Version 4.0, Swafford, Illinois Natural History Survey, Champaign, IL, USA).

\subsection{Human serum samples}

Blood samples and questionnaires were obtained from 195 poultry workers distributed all over Taiwan, including 37 market A workers, 136 and 22 employees from chicken and duck raising farms, respectively, and 146 veterinarians from January 1998 to April 2000. Serum samples were collected after centrifugation of the whole blood at $2000 \mathrm{rpm}$ for 10 min and several aliquots of each sample were stored in $-70{ }^{\circ} \mathrm{C}$ refrigerator.

\subsection{HI and microneutralization test}

Considering the HA subtypes of our market surveillance results and avoiding possible cross reaction of current human NA subtypes (N1 and N2), we chose A/Duck/Czechoslo- 
vakia/56 (H4N6) and A/Shearwater/Australia/1/72 (H6N5) viruses to conduct the serology test. HI test was performed as described [18], and microneutralization test was run according to the standard protocols [20]. Briefly, serum samples were incubated at $56{ }^{\circ} \mathrm{C}$ for $30 \mathrm{~min}$. Serial dilutions of serum samples were made from 1:10, 1:20, 1:40, to 1:1280 in 96-well tissue culture plates. $100 \mathrm{TCID}_{50}$ virus was added into each well, incubated with the diluted serum samples at $37^{\circ} \mathrm{C}$ for $2 \mathrm{~h}$. Then, $1.3 \times 10^{5}$ MDCK cells were added to each well and incubated at $37{ }^{\circ} \mathrm{C}$ for $18-22 \mathrm{~h}$. After removing the supernatant and washing each well with $250 \mu \mathrm{l} \mathrm{PBS}$, the cells were fixed with $80 \%$ acetone solution at $4{ }^{\circ} \mathrm{C}$ for $10 \mathrm{~min}$, and the plates were air dried at room temperature. ELISA was performed using mouse anti-NP monoclonal antibody (CDC, \#VS2208), HRP labeled goat anti-mouse IgG (KPL, cat\# 074-1806), and TMB substrate (KPL, cat\# 50-76-06) to detect influenza virus nucleoprotein. Optical density (OD) values of each well were read by an ELISA reader with a 450 -nm filter. Any well that showed $50 \%$ virus reduction was considered as seropositive.

Table 1

List of avian influenza A virus isolates in poultry market in Taipei, Taiwan

\begin{tabular}{|c|c|c|c|c|}
\hline Virus isolates & Subtypes & Abbreviation & Source counties & Dates of isolation \\
\hline A/Duck/Taiwan/7-8/2000 & $\mathrm{H} 3 \mathrm{~N} 8$ & dtw7-8 & Unknown & $13 / 01 / 2000$ \\
\hline A/Duck/Taiwan/7-17/2000 & $\mathrm{H} 3 \mathrm{~N} 8$ & $\mathrm{dtw} 7-17$ & Unknown & $13 / 01 / 2000$ \\
\hline $\mathrm{A} /$ Duck/Taiwan/7-20/2000 & $\mathrm{H} 3 \mathrm{~N} 8$ & dtw7-20 & Unknown & $13 / 01 / 2000$ \\
\hline A/Duck/Taiwan/7-28/2000 & $\mathrm{H} 3 \mathrm{~N} 8$ & dtw7-28 & Unknown & $13 / 01 / 2000$ \\
\hline A/Duck/Taiwan/8-4/2000 & H3N8 & dtw8-4 & Ilan & $31 / 01 / 2000$ \\
\hline A/Duck/Taiwan/8-6/2000 & $\mathrm{H} 3 \mathrm{~N} 8$ & dtw8-6 & Ilan & $31 / 01 / 2000$ \\
\hline A/Duck/Taiwan/8-8/2000 & $\mathrm{H} 3 \mathrm{~N} 8$ & dtw8-8 & Ilan & $31 / 01 / 2000$ \\
\hline $\mathrm{A} /$ Duck/Taiwan/8-12/2000 & $\mathrm{H} 3 \mathrm{~N} 2$ & $\mathrm{dtw} 8-12$ & Unknown & $31 / 01 / 2000$ \\
\hline A/Duck/Taiwan/8-19/2000 & $\mathrm{H} 3 \mathrm{~N} 1$ & dtw8-19 & Unknown & $31 / 01 / 2000$ \\
\hline A/Duck/Taiwan/8-20/2000 & H3N1 & dtw8-20 & Unknown & $31 / 01 / 2000$ \\
\hline A/Duck/Taiwan/9-3/2000 & H4N4 & dtw9-3 & Yunling & $15 / 02 / 2000$ \\
\hline A/Duck/Taiwan/9-4/2000 & H4N4 & dtw9-4 & Yunling & $15 / 02 / 2000$ \\
\hline A/Duck/Taiwan/9-5/2000 & $\mathrm{H} 4 \mathrm{~N} 1$ & dtw9-5 & Yunling & $15 / 02 / 2000$ \\
\hline A/Duck/Taiwan/9-6/2000 & H4N1 & dtw9-6 & Yunling & $15 / 02 / 2000$ \\
\hline A/Duck/Taiwan/9-23/2000 & H6N1 & dtw9-23 & Unknown & $15 / 02 / 2000$ \\
\hline $\mathrm{A} /$ Duck/Taiwan/10-2/2000 & H4N6 & dtw10-2 & Yunling & $06 / 03 / 2000$ \\
\hline $\mathrm{A} /$ Duck/Taiwan/10-3/2000 & H4N6 & dtw10-3 & Yunling & $06 / 03 / 2000$ \\
\hline A/Duck/Taiwan/10-5/2000 & H4N6 & dtw10-5 & Yunling & $06 / 03 / 2000$ \\
\hline A/Duck/Taiwan/10-6/2000 & H3N6 & dtw10-6 & Yunling & $06 / 03 / 2000$ \\
\hline A/Duck/Taiwan/10-8/2000 & $\mathrm{H} 3 \mathrm{~N} 8$ & dtw10-8 & Yunling & $06 / 03 / 2000$ \\
\hline A/Duck/Taiwan/10-12/2000 & H6N1 & dtw10-12 & Unknown & $06 / 03 / 2000$ \\
\hline A/Duck/Taiwan/10-19/2000 & H4N6 & dtw10-19 & Unknown & $06 / 03 / 2000$ \\
\hline A/Duck/Taiwan/10-21/2000 & H4N2 & dtw10-22 & Changhwa & $06 / 03 / 2000$ \\
\hline A/Duck/Taiwan/10-22/2000 & $\mathrm{H} 4 \mathrm{~N} 2$ & dtw10-22 & Changhwa & $06 / 03 / 2000$ \\
\hline A/Duck/Taiwan/10-24/2000 & $\mathrm{H} 4 \mathrm{~N} 2$ & dtw10-24 & Changhwa & $06 / 03 / 2000$ \\
\hline A/Duck/Taiwan/10-25/2000 & H4N2 & dtw10-25 & Changhwa & $06 / 03 / 2000$ \\
\hline A/Duck/Taiwan/10-27/2000 & H4N2 & dtw10-27 & Changhwa & $06 / 03 / 2000$ \\
\hline A/Duck/Taiwan/10-32/2000 & H4N2 & dtw10-32 & Changhwa & $06 / 03 / 2000$ \\
\hline
\end{tabular}

Unknown source counties: feces of market avians were hard to identify due to mixing effect. 


\section{Results}

\subsection{Market surveillance}

No avian influenza virus was isolated from 600 chicken feces whereas 28 avian influenza viruses were isolated from 700 fecal samples collected through our active market surveillance from October 15, 1999 to March 31, 2000. These 28 isolates were further

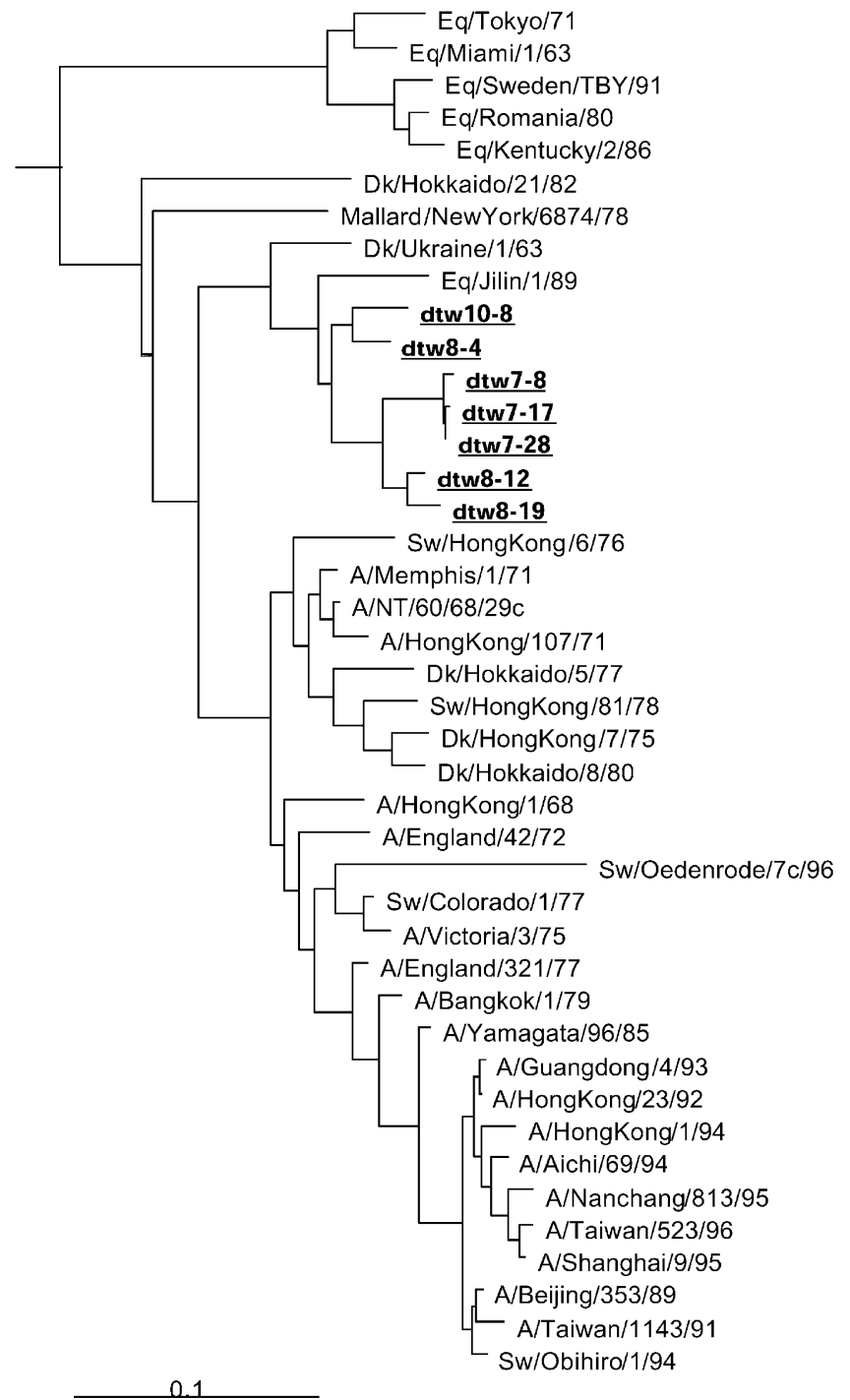

Fig. 1. Phylogenetic tree of H3 (450 bp). 
identified as $12 \mathrm{H} 3$ (including 2 of $\mathrm{H} 3 \mathrm{~N} 1,1$ of H3N2, 1 of H3N6, 8 of H3N8), $14 \mathrm{H} 4$ (including 2 of H4N1, 6 of H4N6, 2 of H4N4, 4 of H4N6), and 2 H6N1 viruses. The isolation rate were $0 \%(0 / 600)$ in chickens and $4 \%(25 / 700)$ in ducks. Table 1 lists epidemiologic characteristics of all these virus isolates, including dates of isolation, and the source

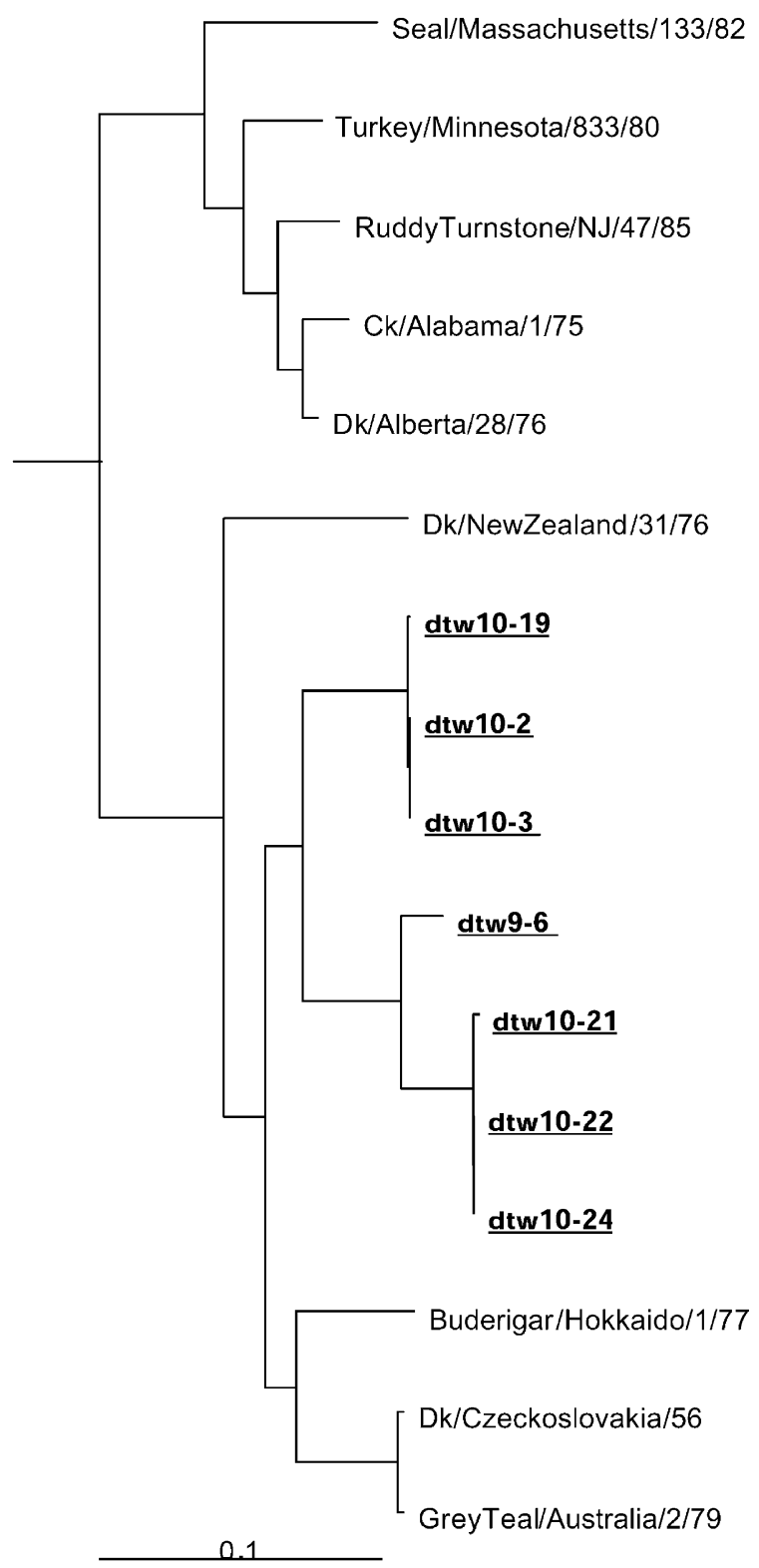

Fig. 2. Phylogenetic tree of H4 (480 bp). 
counties of the ducks that carried the viruses. Half (14/28) of our isolates were of H4 serotype, and H3N8 serotype was the most frequent isolate from the market.

\subsection{Genetic analysis of HA gene}

7 of $12 \mathrm{H} 3,7$ of $14 \mathrm{H} 4$, and $2 \mathrm{H} 6$ market avian influenza virus isolates were further sequenced. The HA gene sequences of our seven $\mathrm{H} 3$ isolates showed homology between $91 \%$ and $99 \%$. All of them had the highest homology with A/Equine/Jilin/89 (H3N8). Phylogenetical analysis of $\mathrm{H} 3$ found that it involved three subgroups (A, B, C) that were correlated with the dates of isolation (Fig. 1). In particular, group A included two viruses, $\mathrm{A} / \mathrm{DK} / \mathrm{Taiwan} / 10-8 / 2000$ and A/DK/Taiwan/8-4/2000, that were isolated from different parts of Taiwan at different months. The phylogenetic tree of seven H4 isolates involved

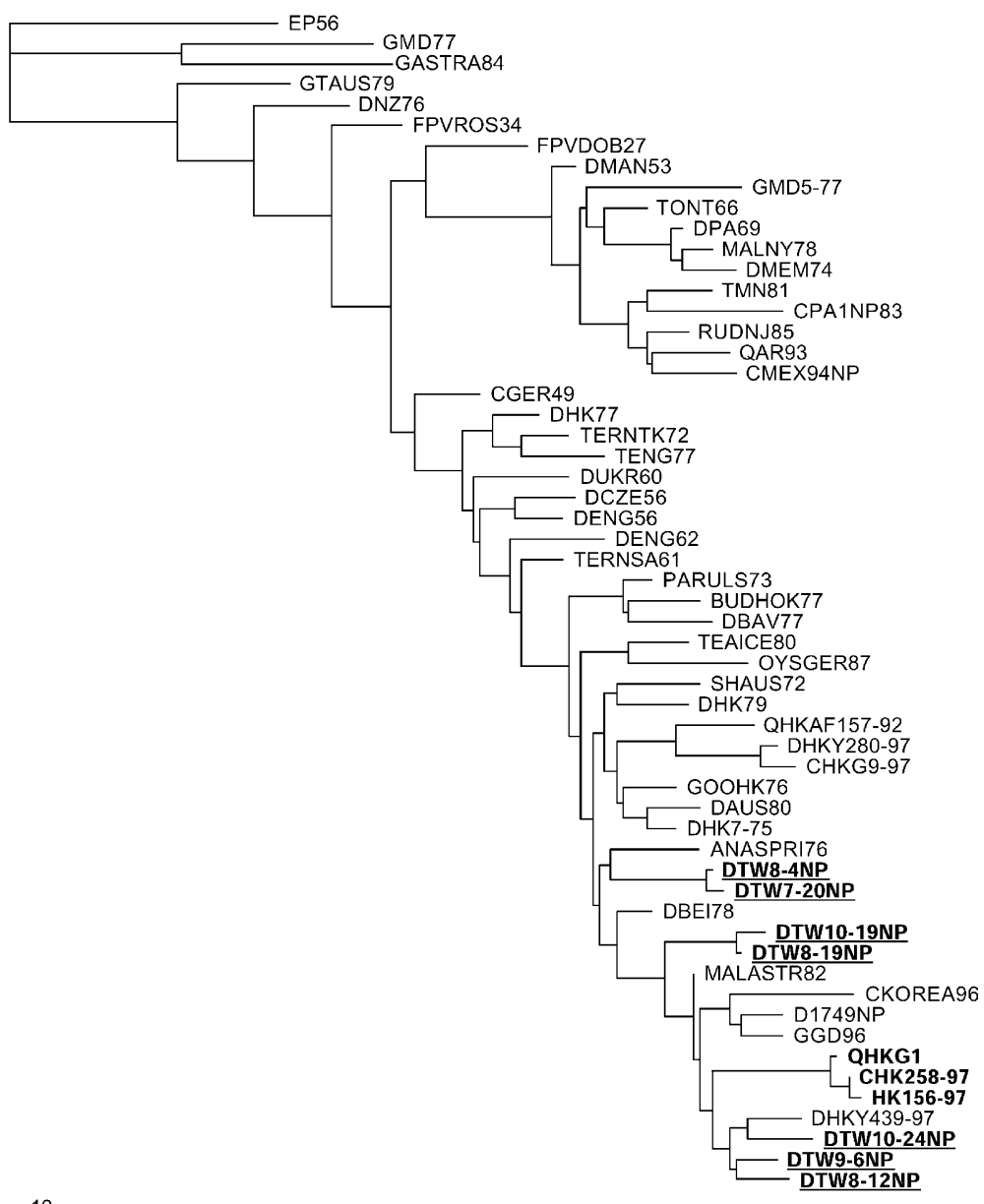

Fig. 3. Phylogenetic tree of NP (586 bp). 
three subgroups with homology between $89 \%$ and $100 \%$ (Fig. 2). Our two additional H6N1 isolates had 90\% sequence homology with A/Teal/Hong Kong/W312/97(H6N1), which had seven genes of high homology (97.1-99.8\%) with Hong Kong H5N1 virus [21]. Most importantly, none of our 28 isolates had multiple basic amino acids at HA1HA2 cleavage site, which was found to correlate with virulence of influenza A viruses [22].

\subsection{Phylogenetic analysis of NP gene}

NP gene sequence data of those seven isolates with the above-mentioned molecular information of HA showed that their homology ranged between $93 \%$ and $99 \%$. Phylogenetic analysis of their NP gene involved four subgroups (A, B, C, D) and none of our isolates was in the lineage of G1 group viruses (Fig. 3). Interestingly, A and B groups were located away from $\mathrm{C}$ and $\mathrm{D}$ groups.

\subsection{Serology results}

All 195 poultry workers and 146 veterinarians distributed all over Taiwan were seronegative by both $\mathrm{HI}$ and microneutralization tests against two avian influenza viruses: A/Duck/Czechoslovakia/56 (H4N6) and A/Shearwater/Australia/1/72 (H6N5).

\section{Discussion}

This is the first document of active market poultry virologic surveillance system established in Taiwan. Our findings on 9 HA-NA serotypes of 28 duck influenza viruses among 700 fecal specimens, but no isolates obtained from 600 chickens, demonstrated a similar pattern with the surveillance data of Hong Kong and Southern China in 1970s [13]. In addition, further sequence analysis showed that these duck influenza viruses isolated from different counties at different months were located in the same Eurasian lineage, implying that sources of avian influenza viruses in Taiwan should be part of the Eurasian gene pool. In addition, the migrating waterfowl might play an important role in the transmission of these duck influenza viruses. The zero isolation rate among chicken fecal samples derived from different breeding farms located in various counties could again be explained by the following reasons: (1) only healthy chickens were sold in the wholesale market, (2) limitation of the method used in collecting field specimens, and (3) a different domestic poultry raising style in Taiwan from Southern China where an ecological niche of different animals was reported. Considering the endemic status of avian influenza viruses in Southern China and Hong Kong in recent years due to viral adaptation via molecular evolution, it is very important for us to monitor avian influenza viruses in Taiwan continuously by the most efficient prevention strategy using a poultry market surveillance system.

Future efforts on avian influenza virus should improve by: (1) collecting more respiratory swabs through market surveillance, (2) phylogenetic analysis of all eight gene segments especially the internal genes of the our isolates, (3) comparing nucleotide and 
amino acid sequences with wild bird and domestic avian influenza virus isolates for investigating possible sources and spreading of those market viruses, and (4) conducting serologic tests against the avian viruses recently isolated from Taiwan. A more comprehensive picture of avian influenza viruses through global surveillance network and international collaboration will be very helpful in vaccine development and prevention of future pandemics.

\section{References}

[1] R.G. Webster, Influenza: an emerging microbial pathogen, in: R.M. Krause (Ed.), Emerging Infections, Academic Press, New York, 1998, pp. 275-300.

[2] M. Ohuchi, M. Orlich, R. Ohuchi, Mutations at the cleavage site of the hemagglutinin after the pathogenicity of influenza virus A/chick/penn/83 (H5N2), Virology 168 (1989) 274-280.

[3] R.G. Webster, R. Rott, Influenza virus A pathogenicity: the pivotal role of hemagglutinin, Cell 50 (1987) 665-666.

[4] T. Ito, J.N.S.S. Couceiro, S. Kelm, L.G. Baum, S. Krauss, M.R. Castrucci, I. Donatelli, H. Kida, J.C. Paulson, R.G. Webster, Y. Kawaoka, Molecular basis for the generation in pigs of influenza A viruses with pandemic potential, J. Virol. 72 (1998) 7367-7373.

[5] C. Scholtissek, Pigs as "mixing vessels" for the creation of new pandemic influenza A virus, Med. Principles Pract. 2 (1990) 65-71.

[6] M.R. Castrucci, I. Donatelli, L. Sidoli, G. Barigazzi, Y. Kawaoka, R.G. Webster, Genetic reassortment between avian and human influenza A viruses in Italian pigs, Virology 193 (1993) 503-506.

[7] E.C.J. Claas, Y. Kawaoka, J.C. DeJong, N. Masurel, R.G. Webster, Infection of children with avian-human reassortant influenza virus from pigs in Europe, Virology 204 (1994) 453-457.

[8] E.C.J. Claas, A.D.M.E. Osterhaus, R.V. Beek, J.C. Jong, G.F. Rimmelzwaan, D.A. Senne, S. Krauss, K.F. Shortridge, R.G. Webster, Human influenza A H5N1 virus related to a highly pathogenic avian influenza Virus, Lancet 351 (1998) 472-477.

[9] K.F. Shortridge, N.N. Zhou, Y. Guan, P. Gao, T. Ito, Y. Kawaoka, S. Kodihalli, S. Krauss, D. Markwell, K.G. Murti, M. Norwood, D. Senne, L. Sims, A. Takada, R.G. Webster, Characterization of avian H5N1 influenza viruses from poultry in Hong Kong, Virology 252 (1998) 331-342.

[10] K. Subbarao, V. Klimov, J. Katz, H. Regnery, W. Lim, H. Hall, M. Perdue, D. Swayne, C. Bender, J. Huang, M. Hemphill, T. Rowe, M. Shaw, X. Xu, K. Fukuda, N. Cox, Characterization of an avian influenza A (H5N1) virus isolated from a child with a fatal respiratory illness, Science 279 (1998) 393-396.

[11] Y.J. Guo, S. Krauss, D.A. Senne, I.P. Mo, K.S. Lo, X.P. Xiong, M. Norwood, K.F. Shortridge, R.G. Webster, Characterization of the pathogenicity of members of the newly established H9N2 influenza virus lineage in Asia, Virology 267 (2000) 279-288.

[12] M. Peiris, K.Y. Yuen, C.W. Leung, K.H. Chan, P.L.S. Ip, R.W.M. Lai, W.K. Orr, K.F. Shortridge, Human infection with influenza H9N2, Lancet 354 (1999) 916-917.

[13] K.F. Shortridge, Isolation of ortho- and paramyxoviruses from domestic poultry in Hong Kong between November 1977 and October 1978 and comparison with isolations made in the preceding two years, Res. Vet. Sci. 28 (3) (1980) 296-301.

[14] Y. Guan, K.F. Shortridge, S. Krauss, R.G. Webster, Molecular characterization of H9N2 influenza viruses: were they the donors of the "intenal" genes of H5N1 viruses in Hong Kong? Proc. Natl. Acad. Sci. U. S. A. 96 (1999) 9363-9367.

[15] Y.P. Lin, M. Shaw, V. Gregory, K. Cameron, W. Lim, A. Klimov, K. Subbarao, Y. Guan, S. Krauss, K.F. Shortridge, R.G. Webster, N. Cox, A. Hay, Avian-to-human transmission of H9N2 subtype influenza A viruses: relationship between H9N2 and H5N1 human isolates, Proc. Natl. Acad. Sci. U. S. A. 97 (2000) 9654-9658.

[16] C.H. Chan, H.K. Shieh, Y.S. Lu, Y.L. Lee, D.F. Lin, Y.K. Liao, M.C. Cheng, Studies on avain influenza in Taiwan, R.O.C. (I): antibody screening, virus isolation and identification, Taiwan J. Vet. Med. Anim. Husb. 53 (1989) 75-88. 
[17] H.K. Shieh, W.J. Huang, J.H. Shien, S.Y. Chiu, L.F. Lee, Y.S. Lu, Studies on avain influenza in Taiwan, R.O.C. (III): isolation, identification, and pathogenicity tests of the virus isolated from breeding chickens, Taiwan J. Vet. Med. Anim. Husb. 59 (1992) 45-55.

[18] A.P. Kendal, M.S. Pereira, J.J. Skehel, Concepts and Procedures for Laboratory-based Influenza Surveillance, Public Health Service, Centers for Disease Control, Atlanta, 1982.

[19] X. Xu, K. Subbarao, N. Cox, Y. Guo, Genetic characterization of the pathogenic influenza a/goose/guangdong/1/96 (H5N1) virus: similarity of its hemagglutinin gene to those of H5N1 viruses from the 1997 outbreaks in Hong Kong, Virology 261 (1999) 15-19.

[20] T. Rowe, R.A. Abernathy, J. Huprimmer, W.W. Thompson, X. Lu, W. Lim, K. Fukuda, N. Cox, J.M. Katz, Detection of antibody to avian influenza A (H5N1) virus in human serum by using a combination of serologic assays, J. Clin. Micobiol. 37 (1999) 937-943.

[21] E. Hoffmann, J. Stech, I. Leneva, S. Krauss, C. Scholtissek, P.S. Chin, M. Peiris, K.F. Shortridge, R.G. Webster, Characterization of the influenza A virus gene pool in avian species in Southern China: was H6N1 a derivative or a precursor of H5N1? J. Virol. 74 (2000) 6309-6315.

[22] J.A. Walker, T. Sakaguchi, Y. Matsuta, T. Yoshida, Y. Kawaoka, Location and character of the cellular enzyme that cleaves the hemagglutinin of a virulent avian influenza virus, Virology 190 (1992) 278-287. 